\title{
COMPETITIVENESS AND EFFICIENCY FOR THE RUBBER TREE PRODUCTION SYSTEM IN SOUTHERN BAHIA (BRAZIL) THROUGH BY THE POLICY ANALYSIS MATRIX (PAM) ${ }^{1}$
}

\author{
Adrielli Santos de Santana ${ }^{2}$ Naisy Silva Soares ${ }^{3 *}$ and Cristian Arnecke Schröder ${ }^{4}$
}

\footnotetext{
${ }^{1}$ Received on 25.03.2018 accepted for publication on 01.11.2018.

${ }^{2}$ Instituto de Pesquisa Econômica Aplicada, Brasília, DF-Brasil. E-mail: <adrielli_santana@outlook.com>.

${ }^{3}$ Universidade Estadual de Santa Cruz, Departamento de Ciências Econômicas, Ilhéus,BA-Brasil. E-mail: < naisysilva@yahoo.com.br>.

${ }^{4}$ Secretaria Municipal de Saúde de Itabuna, Itabuna, BA-Brasil. E-mail: <Schroderca@gmail.com>.

*Corresponding author.
}

\begin{abstract}
The objective of this survey was to analyze the competitiveness and economic efficiency of the rubber tree (Hevea brasiliensis) production system in the southern of Bahia, through by the Policy Analysis Matrix (PAM). The analysis was divided into four categories: profitability analysis; efficiency analysis; protection analysis; and net transfer of policies. The results it possible to affirm that rubber tree production system is a profitable and competitive activity, in the long term, from a private and social point of view. However, the results point out that producers are penalized for the presence of political measures, which focus on product price and productive inputs. In the sensitivity analysis, it was observed that the indicators are sensitive to the fluctuations in the exchange rate and the social income, thus the changes in the price of natural rubber have a strong impact on determining the competitiveness of this productive system.
\end{abstract}

Keywords: Competitiveness; Production cost; Risk analysis

\section{COMPETITIVIDADE E EFICIÊNCIA DO SISTEMA PRODUTIVO DA SERINGUEIRA NO SUL DA BAHIA PELA MATRIZ DE ANÁLISE POLÍtiCA (MAP)}

\begin{abstract}
RESUMO - A presente pesquisa teve como objetivo analisar a competitividade e a eficiência econômica do sistema de produção da seringueira, no Sul do estado da Bahia, pela Matriz de Análise de Políticas (MAP). A análise foi dividida em quatro categorias: análise de lucratividade; análise de eficiência; análise de proteção e transferência líquida de políticas. Os resultados permitem afirmar que a heveicultura é uma atividade lucrativa e competitiva, a longo prazo, do ponto de vista privado e social. Todavia, os resultados apontam que os produtores são penalizados pela presença de medidas politicas incidentes sobre o preço do produto e insumos produtivos. A análise de sensibilidade, permitiu observar sensibilidade dos indicadores às oscilações na taxa de câmbio e receitas sociais. Assim, mudanças no preço da borracha natural têm forte impacto na determinação da competitividade deste sistema produtivo.
\end{abstract}

Palavras-Chave: Competitividade; Custo de produção; Análise de risco. 


\section{INTRODUCTION}

The rubber tree (Hevea brasiliensis) is an origin of the Amazonian region, popularly known as the source of latex, which, when coagulated, becomes the main raw material for the production of tires. The production of centrifuged latex is used in the industry of artifacts aiming at the manufacture of gloves, balloons, coatings, mattresses, medical and pharmaceutical materials, among other applications. The latex is a fluid extracted from the trunk of the rubber tappers, through successive cuts, called Sangria. Subsequently, the vulcanization process occurs, which consists in the warming of this material, until it gains form, strength and elasticity.

The use of rubber tree for the production of natural rubbers had an important role, in the Brazilian economic history, for the generation of wealth and for the development of the northern region of the country. Between 1870 and 1910 years, Brazil became the main producer and exporter of natural rubber, experiencing its first cycle of rubber(Oliveira et al., 2012). However, worldwide competition, mainly from Asian countries, and price variations were some of the factors that led to the increase in producer indebtedness rates and the production crisis (Oliveira et al., 2012).

The cultivation of rubber trees played an important role in the economic development of Bahia. The first seedlings of rubber trees were introduced in 1908, by Leo Zehntner in an attempt to develop studies of cultivation in the region. Only in 1909 began the first rubber plantations, located in Serra da Onça, in the municipality of Canavieiras, in the Franconia's Farm, in the municipality of Una, and at Mucambo's Farm in the municipality of Ilhéus (CEPLAC, 2017).

The prices of natural rubber rose and stimulated the resumption of national production in the early 1940s, being considered the second cycle of rubber in Brazil. However, this new cycle lasted until the end of World War II (1939-1945), when synthetic rubber was used as a substitute for natural rubber. Yet, this resumption of world demand, because of Second World War, stimulated the production of natural rubber in the state. However, during the decade of 1960, the fungus Microcyclus Ulei, which causes the disease, commonly known as Leaf malady, which resulted in decreased production, affected many crop areas (Pires et al., 2006). Between the 1960s and 1980s, the Government launched a set of incentive programs for the development of the rubber culture, aiming for an economic recovery, boosting national production and reducing external dependence, as Brazil imported rubber to supply its domestic demand. In response to government stimuli, Bahia became the largest producer of natural rubber in the 1980s (Pires et al., 2006). Since 1992, the São Paulo natural rubber production has surpassed Bahia, and the producers face the devaluation of Brazilian rubber prices in the face of Asian competitiveness.

In 2017, the production of natural rubber covered 15 Brazilian states, namely: São Paulo, Bahia, Goiás, Mato Grosso, Mato Grosso do Sul, Minas Gerais, Espírito Santo, Pernambuco, Tocantins, Paraná, Maranhão, Acre, Rio de Janeiro, Pará and Amazonas (IBGE, 2017). The natural rubber continues to play a significant role in the Bahian economy, especially, in revenues from exports of agroindustrial products. According to data disclosed by the Superintendence of Economic and Social Studies of Bahia (SEI, 2017), in the year 2015, 211,455 tons of rubbers and their works, equivalent to 45.08 million dollars (US\$ FOB), were exported. These values were surpassed by exports of soybeans, cotton, fruit and their preparations, sisal and cocoa, together with their respective by-products.

From this perspective, the present research is based on the following guiding question: does the rubber tree production system in Southern Bahia present competitiveness and economic efficiency?

The answer to this question has great relevance among the studies that aim to identify the determinant aspects of the competitiveness of Bahian rubber production. Assisting in the identification of weaknesses in the cost structures, contributing to the management of productive capacity and profitability of production. Furthermore, the analysis of the effects of public policies on this productive system serves as a subsidy for the adoption of measures that will assist in decision-making on resource allocations and strategic planning.

In this context, the present work has as general objective to analyze the competitiveness and the effect of public policies on the production system of rubber tree in southern Bahia. Specifically, we sought to: determine the private and social profitability of the productive system; measure indicators that assess the degree of competitiveness, economic efficiency and the effects of policies in this activity, considering the private and social results; and to analyze the sensitivity of private and social indicators to changes in the exchange rate and social prices.

Revista Árvore. 2018;42(6):e420606 


\section{METHOD AND MATERIAL}

The data corresponding to the production costs of rubber tree, including the private prices of marketable inputs and domestic factors, were obtained from the work of the Virgens Filho (2003), whose values were corrected by applying the General Index of Prices (IGPdi) of Getúlio Vargas Foundation (FGV), at prices of January 2017.

To represent the private price of the product, we used the price of the kilo of the latex clot with DRC (Dry Rubber Content) of 57\% extracted from the rubber tree supplied by the National Supply Company (Conab, 2017 ), considering the price paid to the producer in Bahia of R $\$ 2.11 / \mathrm{Kg}$. The social price of natural rubber was based on international prices. For the rubber tree production system, it was considered the average of the latex quotations in the Malasya (Malaysian Rubber Board, 2017), equivalent to $710.70 \mathrm{Sen} / \mathrm{kg}$ or US\$1.62/ $\mathrm{kg}$. In this case, an exchange rate of R\$3.196 was applied, corresponding to the average of the month of January available in the Central Bank of Brazil (BACEN, 2017), resulting in the following social price: $\mathrm{R} \$ 5.17 / \mathrm{Kg}$ of latex clot.

The social prices of production inputs were estimated based on international prices. The labor, which corresponds to domestic factors of production, was equated to the average wage prevailing in national territory to the average wage of Indonesia. The choice of this country was motivated by its representativeness in the rubber production, occupying the second position in the ranking of the largest producers of natural rubber. As for the most weight marketable inputs in the cost spreadsheet, prices corresponding to the value of African and Asian exports to Brazil were estimated, made available in the Aliceweb database of the Ministry of Industry, Foreign Trade and Services (MDIC), converting them from US\$ FOB $/ \mathrm{Kg}$ to $\mathrm{R} \$ / \mathrm{kg}$. The other products, when considering the absence of divergences of policies, their social prices become approximations of private prices.

It was adopted in the development of this research the production costs for the model spacing 8.0 meters between the rows and 2.5 meters between plants $(8.0 \mathrm{~m}$ $\mathrm{x} 2.5 \mathrm{~m}$ ). This would result in booths with a maximum capacity of 500 plants per hectare, being the most recommended model for non-traditional areas of cultivation of rubber tree (Virgens Filho, 2003; Alvarenga, 2014).

It was used for the analysis of the Policy Analysis Matrix (PAM) which is the result of the product of two accounting identities: (i) the profitability, which is defined as the difference between the revenues and the productive costs; and (ii) the effects of divergences, associated with distortions of policies and/or market failures, observed through the difference between private prices, practiced on the market, and social, or international prices, which represent the costs of opportunity (Monke and Pearson, 1989; Araújo, 2015).

Table 1 - Political Analysis Matrix .

Tabela 1 - Matriz de análise política.

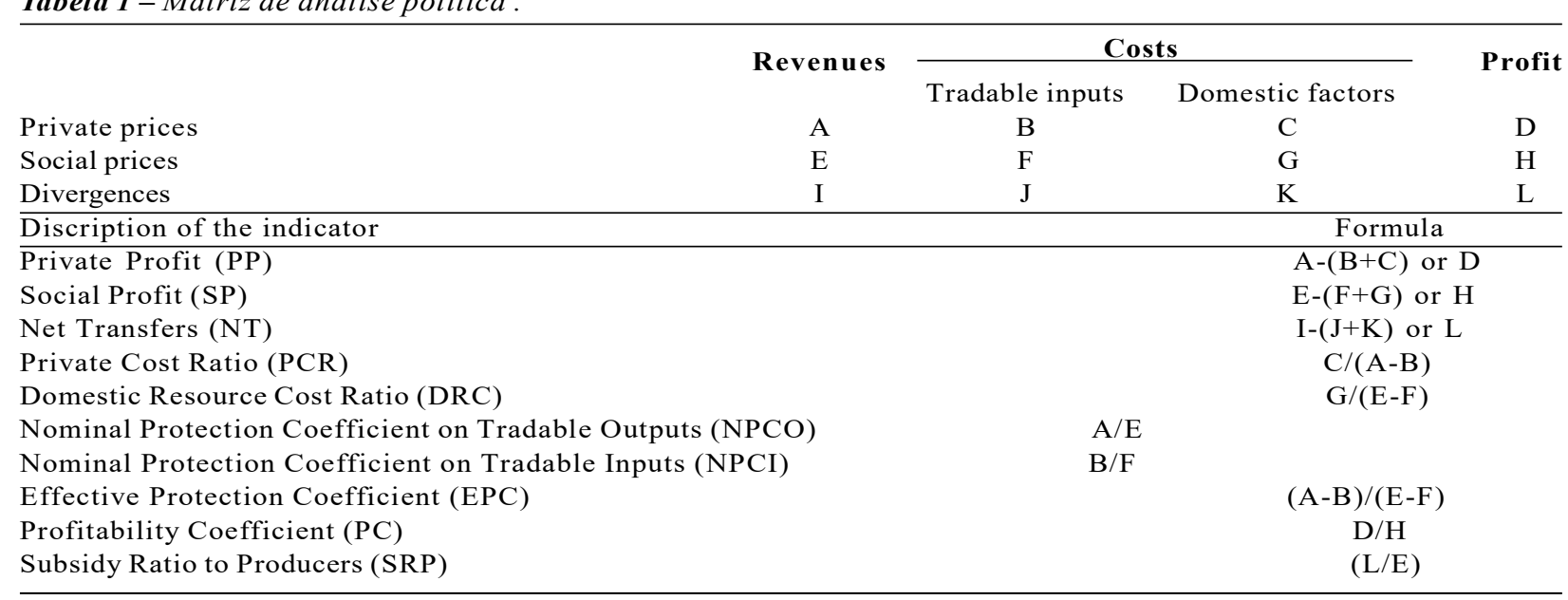

Source: Prepared by authors from Monke and Pearson (1989). 
Table 2 - Results of the Political Analysis Matrix .

Tabela 2-Resultado da Matriz de Análise Política .

\begin{tabular}{|c|c|c|c|c|}
\hline & \multirow{2}{*}{ Revenues(R\$/ha) } & \multicolumn{2}{|c|}{ Cost (R\$/ha) } & Profit(R\$/ha) \\
\hline & & Tradable inputs & Domestic factors & \\
\hline Private prices & $21.148,53$ & $23.076,19$ & $10.858,07$ & $-12.785,73$ \\
\hline Social prices & $51.894,28$ & $20.125,50$ & $7.166,33$ & $24.602,45$ \\
\hline Divergences & $-30.745,75$ & $2.950,69$ & $3.691,74$ & $-37.388,19$ \\
\hline
\end{tabular}

Source: Search results.

The PAM provides data on revenue, costs and profits from the agricultural system. The competitiveness analysis derives from the measurement of the indicators obtained in the empirical construction of the matrix (Table 1).

The purpose of the analysis of profitability is to evaluate the economic viability of the productive system. To achieve this goal, three PAM indicators are used. These are Private Profit (PP), Social Profit (SP) and Profitability Coefficient (PC).

The efficiency analysis of the production systems considered the indicators of Private Cost Ratio (PCR) and Domestic Resource Cost Ratio (DRC). Thus indicating the participation of domestic factors to the added value, being the first used at private prices and the second at social prices.

The analysis of the protection of the productive system was interpreted from the level of taxation and subsidies that affect them. The following indicators are used to achieve this objective: Nominal Protection Coefficient on Tradable Outputs (NPCO), Nominal Protection Coefficient on Tradable Inputs (NPCI) and Effective Protection Coefficient (EPC).

In order to estimate the effects of policy transfers, i.e. the loss of the producer as a result of market distortions and the effects of the policies, the indicators of Net Transfers (NT) and Subsidy Ratio to Producers (SRP)

After the estimates of the PAM values, a risk analysis was performed to verify the sensitivity of the indicators subjected to variations in the exchange rate and social prices. In addition, this analysis allows creating scenarios in the face of changes or uncertainties in estimating values. The variations were between $-10 \%$ to $10 \%$ in the exchange rate and in the social prices in the estimated indicators for the rubber tree production system. To do so, the Monte Carlo method was used, using the software@RISK that allows analyzing the effects of 1,000 interactions, given the input variables (exchange rate and social prices) and the output variables (the indicators of the PAM), adopting a triangular distribution.

\section{RESULTS}

The data table 2 illustrates the empirical construction of PAM, obtained through the private and social values of revenues (price multiplied by the quantity produced), production costs (sum of domestic and marketable inputs) and profits (difference between revenues and Costs).

The results of the private and social indicators provided by the accounting matrix for the rubber tree production system is presented in Table 3 .

The data table 4 is the sensitivity statistics of the PAM indicators for the rubber tree production system, given variations between $-10 \%$ and $10 \%$ in the exchange rate.

The data table 5 shows the effects of variations of $-10 \%$ to $10 \%$ on the social values on the indicators measured for the rubber tree production system.

\section{DISCUSSIONS}

The Table 2 shows that the social prices of natural rubber are higher than private prices, so social revenues are higher than private revenues. Denoting that the

Table 3 - Results of the PAM indicators for production systems of rubber tree.

Tabela 3 - Resultados dos indicadores da MAP para os sistemas de produção da seringueira.

\begin{tabular}{cc}
\hline Indicator & Result \\
\hline PP & $\mathrm{R} \$-12.785,73$ \\
SP & $\mathrm{R} \$ 24.602,45$ \\
NT & $\mathrm{R} \$-37.388,19$ \\
PCR & $-5,63$ \\
DRC & 0,23 \\
NPCO & 0,41 \\
NPCI & 1,15 \\
EPC & $-0,06$ \\
PC & $-0,52$ \\
SRP & $-0,72$ \\
\hline Source: Search results.
\end{tabular}

Revista Árvore. 2018;42(6):e420606 
Table 4 - Sensitivity statistics of PAM indicators for the rubber production system, whit variations between $-10 \%$ and $10 \%$ in the exchange rate.

Tabela 4 - Estatísticas de sensibilidade dos indicadores da MAP para o sistema de produção da seringueira, com variações entre $-10 \%$ e $10 \%$ na taxa de câmbio.

\begin{tabular}{|c|c|c|c|c|c|c|c|c|c|}
\hline \multirow{2}{*}{ STATISTICS } & \multicolumn{8}{|c|}{ OUTPUT VARIABLES } & \multirow[b]{2}{*}{ SRP } \\
\hline & PP & SP & NT & PCR & DRC & NPCO & EPC & $\mathrm{PC}$ & \\
\hline Minimum & $-12.785,73$ & $21.538,13$ & $-40.466,07$ & $-5,63$ & 0,22 & 0,37 & $-0,07$ & $-0,59$ & $-0,73$ \\
\hline Maximum & $-12.785,73$ & $27.680,34$ & $-34.323,86$ & $-5,63$ & 0,23 & 0,45 & $-0,05$ & $-0,46$ & $-0,71$ \\
\hline Average & $-12.785,73$ & $24.602,55$ & $-37.388,29$ & $-5,63$ & 0,23 & 0,41 & $-0,06$ & $-0,52$ & $-0,72$ \\
\hline Mode & $-12.785,73$ & $24.587,03$ & $-37.372,77$ & $-5,63$ & 0,23 & 0,41 & $-0,06$ & $-0,52$ & $-0,72$ \\
\hline $\begin{array}{l}\text { Standard } \\
\text { deviation }\end{array}$ & 0,00 & $1.302,84$ & $1.302,84$ & 0,00 & 0,00 & 0,02 & 0,00 & 0,03 & 0,00 \\
\hline \multicolumn{10}{|c|}{ PERCENTILES } \\
\hline $10 \%$ & $-12.785,73$ & $22.837,41$ & $-39.153,60$ & $-5,63$ & 0,22 & 0,39 & $-0,07$ & $-0,56$ & $-0,73$ \\
\hline $20 \%$ & $-12.785,73$ & $23.427,93$ & $-38.565,34$ & $-5,63$ & 0,22 & 0,39 & $-0,06$ & $-0,55$ & $-0,72$ \\
\hline $30 \%$ & $-12.785,73$ & $23.880,70$ & $-38.110,94$ & $-5,63$ & 0,22 & 0,40 & $-0,06$ & $-0,54$ & $-0,72$ \\
\hline $40 \%$ & $-12.785,73$ & $24.265,08$ & $-37.725,31$ & $-5,63$ & 0,23 & 0,40 & $-0,06$ & $-0,53$ & $-0,72$ \\
\hline $50 \%$ & $-12.785,73$ & $24.601,40$ & $-37.390,01$ & $-5,63$ & 0,23 & 0,41 & $-0,06$ & $-0,52$ & $-0,72$ \\
\hline $60 \%$ & $-12.785,73$ & $24.935,74$ & $-37.051,97$ & $-5,63$ & 0,23 & 0,41 & $-0,06$ & $-0,51$ & $-0,72$ \\
\hline $70 \%$ & $-12.785,73$ & $25.320,22$ & $-36.670,43$ & $-5,63$ & 0,23 & 0,42 & $-0,06$ & $-0,50$ & $-0,72$ \\
\hline $80 \%$ & $-12.785,73$ & $25.773,59$ & $-36.219,63$ & $-5,63$ & 0,23 & 0,42 & $-0,06$ & $-0,50$ & $-0,72$ \\
\hline $90 \%$ & $-12.785,73$ & $26.365,44$ & $-35.627,30$ & $-5,63$ & 0,23 & 0,43 & $-0,06$ & $-0,48$ & $-0,71$ \\
\hline
\end{tabular}

Source: Search results.

prices practiced in the southern region of Bahia are below international prices. These results suggest the presence of distorted policies that penalize the producer, directly affecting the profitability of this system. Among the policies that most fall within this context, we highlight those that directly and/or indirectly focus on the tax burden, interest rates, foreign exchange and commercial policies.
On the other hand, the production costs were higher in the south of Bahia than at international prices. The private cost with marketable inputs was higher in $14.66 \%$ than the social values. While the cost of domestic factors presented higher private values in $51.51 \%$. Labor cost is predominant in the composition of domestic factors as a function of intensive use in production. Allied to the higher wage remuneration practiced in Brazil

Table 5 - Sensitivity statistics of MAP indicators for the rubber production system, given variations between $-10 \%$ and $10 \%$ in revenues and costs, at social prices.

Tabela 5 - Estatísticas de sensibilidade dos indicadores da MAP para o sistema de produção da seringueira, dada variações entre $-10 \%$ e $10 \%$ nas receitas e custos, a preços sociais.

\begin{tabular}{|c|c|c|c|c|c|c|c|c|c|}
\hline \multirow{2}{*}{ STATISTICS } & \multicolumn{9}{|c|}{ OUTPUT VARIABLES } \\
\hline & PP & SP & $\mathrm{NT}$ & PCR & DRC & $\mathrm{NPCO}$ & EPC & $\mathrm{PC}$ & SRP \\
\hline Minimum & $-12.785,73$ & $18.164,26$ & $-43.146,18$ & $-5,63$ & 0,18 & 0,37 & $-0,08$ & $-0,70$ & $-0,77$ \\
\hline Maximum & $-12.785,73$ & $30.360,45$ & $-30.949,99$ & $-5,63$ & 0,29 & 0,45 & $-0,05$ & $-0,42$ & $-0,66$ \\
\hline Average & $-12.785,73$ & $24.602,42$ & $-37.388,16$ & $-5,63$ & 0,23 & 0,41 & $-0,06$ & $-0,52$ & $-0,72$ \\
\hline Mode & $-12.785,73$ & $23.740,98$ & $-36.526,71$ & $-5,63$ & 0,22 & 0,41 & $-0,06$ & $-0,52$ & $-0,72$ \\
\hline \multirow[t]{2}{*}{$\underline{\text { Standard deviation }}$} & 0,00 & $2.254,57$ & $2.254,57$ & 0,00 & 0,02 & 0,02 & 0,00 & 0,05 & 0,02 \\
\hline & \multicolumn{9}{|c|}{$\begin{array}{l}\text { PERCENTILES } \\
\end{array}$} \\
\hline $10 \%$ & $-12.785,73$ & $21.668,29$ & $-40.364,55$ & $-5,63$ & 0,20 & 0,39 & $-0,07$ & $-0,59$ & $-0,74$ \\
\hline $20 \%$ & $-12.785,73$ & $22.609,74$ & $-39.416,64$ & $-5,63$ & 0,21 & 0,39 & $-0,06$ & $-0,57$ & $-0,74$ \\
\hline $30 \%$ & $-12.785,73$ & $23.347,16$ & $-38.661,34$ & $-5,63$ & 0,22 & 0,40 & $-0,06$ & $-0,55$ & $-0,73$ \\
\hline $40 \%$ & $-12.785,73$ & $23.967,19$ & $-38.055,71$ & $-5,63$ & 0,22 & 0,40 & $-0,06$ & $-0,53$ & $-0,73$ \\
\hline $50 \%$ & $-12.785,73$ & $24.584,60$ & $-37.373,85$ & $-5,63$ & 0,23 & 0,41 & $-0,06$ & $-0,52$ & $-0,72$ \\
\hline $60 \%$ & $-12.785,73$ & $25.268,71$ & $-36.756,11$ & $-5,63$ & 0,23 & 0,41 & $-0,06$ & $-0,51$ & $-0,72$ \\
\hline $70 \%$ & $-12.785,73$ & $25.869,76$ & $-36.135,67$ & $-5,63$ & 0,24 & 0,42 & $-0,06$ & $-0,49$ & $-0,71$ \\
\hline $80 \%$ & $-12.785,73$ & $26.613,14$ & $-35.408,66$ & $-5,63$ & 0,24 & 0,42 & $-0,06$ & $-0,48$ & $-0,70$ \\
\hline $90 \%$ & $-12.785,73$ & $27.568,79$ & $-34.454,59$ & $-5,63$ & 0,25 & 0,43 & $-0,06$ & $-0,46$ & $-0,69$ \\
\hline
\end{tabular}

Source: Search results. 
compared to Indonesia, used as representative of international prices, caused domestic factors in national territory to present higher values. In this analysis, the use of slave labor, the breach of labor laws or employment contracts and/or any adverse conditions that affect wage remuneration, due to the unavailability of data and Estimation mechanisms.

It is observed that private profit is lower than social profit, and negative. This result is justified, among other factors, by the low price of natural rubber in the region, by limiting the research data that covered a period of 12 years, and within the interpretation of PAM by absence of policy measures benefiting producers and production in that region.

\subsection{Profitability Analysis}

Firstly, to analyze the efficiency of the productive system, it is necessary to analyze the Profit sharing in revenues or results (PSR), expressed by the ratio between profit and revenue, in order to verify the profitability and viability of the activity. In this context, the PAM presented negative private profit equal to $\mathrm{R} \$ 12,785.73$ and positive social profit equal to $\mathrm{R} \$ 24,602.45$, resulting in PSR equivalent to $-60.46 \%$, corresponding to private values, and $47.41 \%$ to social prices.

In this context, the interpretation of the PC allows numerically measuring the difference between the values of PP and SP, and shows the amount of social profit that was transferred to the productive systems in the face of these policy failures. According to Freitas (2013), the PC indicates "the profit that would be obtained in the absence of distortion-causing policies". The PC found was -0.52 , demonstrating that the producer is not benefiting from the current policies, Taxing on productive systems that directly reduce PP. In summary, the results of $\mathrm{PC}$ indicate the absence of protecionism in the productive system.

The interpretation of $\mathrm{PC}$ in percentage terms (1PCx100) represents the vulnerability of the productive system in relation to the policies. With a PC of -0.52 , the interpretation of this indicator indicates that the producer suffers a taxing of $152 \%$, indicating a strong penalty.

\subsection{Efficiency analysis}

The production of natural rubber is characterized by labor intensive, indicating the factor work as totality in the composition of domestic inputs. According to Lopes et al. (2012), primary activities normally intensives in labor and exposed to suffering losses caused by divergences of policies, present low profitability, in general. From this analogy, the indicated PCR is used to measure the capacity of the system to cover the costs of domestic factors and remain competitive.

The PCR index found was -5.63 . The absence of literatures whose PCR assumes negative value prevents conclusions about the performance of the rubber tree production system, based on this indicator. However, it is assumed that its negative results are conditioned to the period considered in the investigation, assuming, therefore, that these would be altered at each additional time unit. For the interpretation of this indicator, it is understood that the lower the value found, the better its performance. Therefore, it is inferred that the production system of rubber tree was competitive, by the cost of domestic factors.

On the other hand, the DRC signals the relative efficiency of the productive systems, measuring and comparing their social benefits. This indicator follows the same reasoning as the indicator of private profitability, in which the minimization of the DRC "is equivalent to maximizing the social profits" (Moss, 2006). Thus, the result is equal to 0.23 , indicating the presence of economic efficiency and competitive advantage to social values, that is, in relation to the international price of the products. Therefore, for each R $\$ 1.00$ saved with the importation, $\mathrm{R} \$ 0.23$ of domestic resources would be used.

Compleming this analysis, we used the indicator of Total Productivity of Factors (TPF) to measure the ratio between the total value of the product and the value of the total cost, obtained through the sum of the costs with domestic factors and the cost with marketable inputs. The TPF indicator captures better the efficiency level of the productive activities, allowing the execution of comparative analyses among them, or comparing changes in its productive structure, such as "change in the quality of a product, improvement of human capital, technology in all links, adequate funding, research and development, among others" (Araújo, 2015). In summary, the TPF indicates the rate of return of investments of the factors used by the system, and its relative position in comparison with the others.

Revista Árvore. 2018;42(6):e420606 
The results of the PTF values demonstrated that there is a positive relationship of efficiency and competitiveness. Alternatively, it is possible to interpret these indicators as follows: the product at private prices, measured at market prices, is higher than levels $\mathrm{R} \$ 0.62$ to the costs with marketable inputs and domestic factors for the production system intercropped. The product at social prices, when calculated at market prices, exceeds the costs of marketable inputs and domestic factors in $\mathrm{R} \$ 1.90$.

\subsection{Protection analysis}

The function of the NPCP is to estimate the level and flow of taxes in the productive systems, that is, if there are transfers of income from the system to the company, via taxes, or from the company to the agricultural activity via tax and/or subsidies to the producer. The result of the NPCO found was equal to 0.41 , indicating a lack of protection of this activity, by means of taxative policies and taxation, since its prices are below social prices. Therefore, the producers receive $59 \%$ less than the prices practiced internationally.

From the point of view of the NPCI, which measures the degree of transfer or the level of protection of marketable inputs, the result was equivalent to 1.15 . Therefore, it is stated that there is a transfer of income from producers to society, because the costs of marketable inputs have been increased by the distortions of policies, i.e., the inputs are taxed. As for the rubber tree production system, it is inferred that there is no protection or disprotection of marketable inputs, due to the private values of inputs approaching their social values.

As mentioned by Moss (2006), NPCO and NPCI have an inverse relationship, since the increase in private prices for the product positively affects the level of $\mathrm{PP}$, while the increase in private prices of marketable inputs negatively affects the PP level. Remaking the same analogies proposed by the authors, the smaller the NPCO and the higher the NPCI, the higher the transfers of the producers.

Despite setting up an important indicator to measure the protection of productive activities, the nominal protection analysis is limited to comparisons between values practiced in the domestic market (private price) and the values practiced in the international market ( Social price). In this regard, Freitas (2013) states that analysis of the EPC becomes more efficient to measure protection, as it evaluates transfers resulting from policies, both on the level of revenues and for marketable inputs. Also verifying whether such policies exert stimuli or disincentives on agricultural systems.

The calculated coefficient showed a lower value than the unit, in -0.06 , as presented by Lopes et al. (2012), for EPC smaller than 1 (EPC $<1)$, it is interpreted that the productive activity is unprotected and has high taxations and additional costs that can reach $100 \%$.

\subsection{Policy Transfer Analysis}

As a result of this analysis, it was observed that the cultivation of rubber tree showed an indicator of NT equivalent to $\mathrm{R} \$-37,388.19$, per hectare, in a total of 12 years. Demonstrating how much the producer loses because of market distortions and policy effects. Despite the great magnitude of the difference observed between the private values, earned by the producers, and the social values prevailing in the international market, for Freitas (2013), there are no indications that point to a direct relationship between the imbalance of profitability and economic unfeasibility, justifiable through the positive values of PP verified in its application of PAM for dairy production. Sharing the author's view, the present research, based on the results of the PP, confirms that the discrepancies between social and private prices do not affect the economic viability of the productive system.

To complement the analysis of policy transfers, the level of taxation of the system was measured in order to show, numerically, the volume of taxations and, consequently, the loss of profitability. An equal - 0.72 SRP was found whose negative value expresses the presence of taxations. In terms of general taxing level (GTL), which represents the SRP module in percentage terms, the results were approximately $72.05 \%$. The calculation of the SRP, or GTL, encompasses the effects of all taxation policies, taxes, charges and interest on the profitability of productive activities. It demonstrates, at social prices, the volume of the product or revenues needed to ensure the economic efficiency of the system (Sousa et al., 2011). The higher the value of these indicators, the higher the tax burden. The results express the amount of disincentives, in percentage terms, generated by failures and distortions of policies.

\subsection{Sensitivity analysis}

By varying the exchange rate, the results showed that only $10 \%$ of the SP values found are below R\$ $22,837.41$ and $10 \%$ of these values are above $\mathrm{R} \$ 26,365.44$, 
with the minimum and maximum values found, respectively, $\mathrm{R} \$ 21,538.13$ and $\mathrm{R} \$ 27,680.34$. The simulation for the rubber tree production system presented negative NT in all observations. On average, the value found was $\mathrm{R} \$-37,388.29$, and $10 \%$ of the values found for the NT were between R \$ -40,466.07 and R \$ -39,153.60, and $10 \%$ of the values are between $\mathrm{R} \$-35,627.30$ and $\mathrm{R} \$-34,323.86$. Being the standard deviation of SP and NT equal to R\$1,302.84 (Table 4).

Considering the results of the DRC, $40 \%$ of the values were equal to 0.22 and $60 \%$ corresponded to $0.23 \%$, demonstrating little significant variation. Regarding the NPCO, the results ranged from 0.37 to 0.45 . For the EPC these variations are between -0.07 and -0.05 . It was found in both cases that changes in exchange rate scenarios did not generate indicators larger than the unit (1), for the rubber tree production system. Considering $\mathrm{PC}$, the minimum and maximum results were, respectively, -0.59 and-0.46, and only $20 \%$ of the interactions performed are less than or equal to -0.55 , and $20 \%$ are above -0.50 . The SRP ranged between- 0.73 and -0.71 , and $75 \%$ of the values found equal to- 0.72 , demonstrated, therefore, that the simulation of variations in the exchange rate did not create high discrepancies between the PAM indicators for the rubber tree production system (Table 4).

When the social price varies, the SP and the NT present minimum values equal to $\mathrm{R} \$ 18,164.26$ and $\mathrm{R} \$-$ $43,146.18$, and maximum values equal to $R \$ 30,360.45$ and $\mathrm{R} \$-30,949.99$ respectively. As shown in the previous simulations, the PP for the rubber tree production system presents negative values, which is not influenced by social values. Therefore, regardless of the variation in social prices and the amount of SP, the NT for this system will always be negative. This behavior causes PC to also present negative values, with $10 \%$ of the interactions presenting results lower than -0.59 , and $10 \%$ were higher than -0.46 . The mean for the DRC was 0.23 , with minimum and maximum values equal to 0.18 and 0.29 . Considering the NPCO. The results varied slightly in relation to the original indicator of 0.41 found in the calculation of PAM, between 0.37 and 0.45 in the sensitivity analysis. Similarly, the EPC with variation between -0.08 and- 0.05 was observed. Finally, the SRP showed variations between -0.77 and -0.66 , and $20 \%$ of the interactions were lower or equal to- 0.74 and $10 \%$ were greater than or equal to -0.69 (Table 5).

Regarding the degree of sensitivity of the indicators of the map, in response to variations of $10 \%$ in the exchange rate and social values, it was found that the increase of $10 \%$ in revenues at social price increased the social profit by $13 \%$ and $21 \%$, respectively. While the $10 \%$ increase in the cost of marketable inputs reduced the SP by $8 \%$ and domestic factors reduced by $3 \%$. The NT would increase by $8 \%$ and $14 \%$, with the increase of the exchange rate and the social revenues, and would reduce $5 \%$ and $2 \%$, with the increase of costs with marketable inputs and domestic factors, respectively.

The $10 \%$ increase in the exchange rate reduces at levels of $2 \%, 9 \%, 11 \%$ and $11 \%$ the indicators DRC, NPCO, EPC and PC, respectively. In addition, the increment in revenues, kept everything more constant, reduces the DRC, NPCO, EPC and PC by $14 \%, 9 \%, 14 \%$ and $17 \%$.

The CPNO is not sensitive to variations in social costs. In addition, the EPC does not vary due to changes in domestic factors. The justification for these two situations is that these components are not part of the calculation of these indicators.

In general, map indicators were more sensitive to changes in social revenues than exchange rate variations and production costs. Indicating, therefore, that measures that stimulate the increase of revenues, both through stimulus to production and prices, tend to benefit the behavior of the indicators of the PAM. However, measures aimed at reducing production costs are important to ensure the efficiency of the productive system and increase the profit margin.

\section{CONCLUSIONS}

With the analyses carried out, it was verified that the production system of rubber tree was efficient because it was able to cover the costs with domestic factors, not showing loss of competitiveness.

In general, it was observed that the producer suffers penalties due to taxative policies and taxation, thus occurring a transfer of income from the producer to society. This activity suffers a lack of protection from governmental policies, in this case represented by taxes and tributes, interest rates, foreign exchange and trade policies that affect production and commercialization. However, the rubber tree production represents an attractive activity, from a competitive standpoint, given the values of revenues and production costs, and presents comparative advantage from the perspective of international (social) prices.

Revista Árvore. 2018;42(6):e420606 
As for public policies, high tax and tax rates focus on marketable inputs and domestic factors contributing to the loss of competitiveness of production systems. The high production cost is one of the main obstacles that penalize the producer in the region, reflecting a reality of the Brazilian context. Among the measures that can be implemented to improve the competitiveness of rubber tree production in the south of Bahia, we highlight: (i) the reduction of the tax burden incident on inputs and production factors, and on the price of the product; (ii) greater investment in Research and Development (R\&D) aimed at increasing product quality, productivity and resource allocation efficiency; (iii) expansion of funding policies and granting of agricultural credit to small and medium-sized producers; (iv) greater control of commercial mechanisms, such as export and import taxes, subsidies, restrictions and other trade policies and; (v) the maintenance of a macroeconomic policy compatible with investment interests, including inflationary control, maintenance of favorable interest rates and a foreign exchange policy that stimulates exports, favoring the competitiveness In the international market.

\section{ACKNOWLEDGEMENTS}

To Coordination for the Improvement of Higher Education Personnel (CAPES), by the funding granted.

\section{REFERENCES}

Alvarenga AP. Implantação e condução da cultura seringueira. In: Alvarenga AP, Carmo CAFS, editors. Seringueira. 2a . ed. Viçosa, MG: Epamig Zona da Mata; 2014. p.391-434.

Araújo WBC. Matriz de análise política aplicada à cadeia produtiva da manga no município de Petrolina, Pernambuco [dissertação]. Fortaleza: Universidade Federal do Ceará; 2015.

Banco Central do Brasil - BACEN. Cotações e boletins. 2017. [acessado: 8 set. 2017]. Disponível em: http://www4.bcb.gov.br/pec/taxas/port/ ptaxnpesq.asp? $\mathrm{id}=$ txcotacao.

Comissão Executiva do Plano da Lavoura Cacaueira-CEPLAC. Antecedentes. 2017. [acessado: 20 mar. 2017]. Disponível em: http:// www.ceplac.gov.br/radar/heveicultura/ heveicultura_antecedentes_e_justificativas.pdf.
Companhia Nacional de Abastecimento Conab. Preços agropecuários. 2017. [acessado: 23 abr. 2017]. Disponível em: http:// www.conab.gov.br.

Freitas JB. Competitividade, eficiência econômica e efeitos de políticas em diferentes níveis tecnológicos na cadeia produtiva do leite em pó integral no Rio grande do Sul: uma análise do método da Matriz de Análise Política (MAP) [dissertação]. Porto Alegre: Universidade Federal do Rio Grande do Sul; 2013.

Instituto Brasileiro de Geografia e Estatística IBGE. Sidra. Produção Agrícola Municipal. 2017. [acessado: 15 out. 2018]. Disponível em: https:// sidra.ibge.gov.br/pesquisa/pam/tabelas.

Lopes MR, Oliveira AJ, Belarmino LC, Torres DAP, Talamini DJD, Martins FM, et al. Matriz de análise política: metodologia e análise. Brasília, DF: Embrapa; 2012.

Malaysian Rubber Board. Malaysian Rubber Exchange. 2017. [acessado: 15 set. 2017]. Disponível em: http://www3.lgm.gov.my/mre/ MonthlyPrices.aspx.

Monke AE, Pearson SR. The policy analysis matrix for agricultural development. New York: Cornell University Press; 1989.

Moss SR. Competitividade da produção do café arábica em Minas Gerais e São Paulo [dissertação]. Viçosa, MG: Universidade Federal de Viçosa; 2006.

Oliveira WP, Trindade JRB, Machado NM.

Borracha, nordestino e floresta: a economia e a sociedade amazônica nos dois ciclos gomíferos. Cadernos CEPEC, 2012;1(1):8-35. [acessado: 20 abr. 2017]. Disponível em: http:// ppgeconomia.ufpa.br/documentos/ Cadernos\%20CEPEC\%20Vol.01\%20n01\%20\% 28ffe2012\%29.pdf.

Pires MM, Midlej MMB, Alves JM, Araújo LV. Borracha natural no estado da Bahia. In: Alvarenga AP, Rosado PL, Carmo CAFS, Tôsto SG, editors. Seringueira: aspectos econômicos sociais e perspectivas para o seu fortalecimento. Viçosa, MG: Epamig/Embrapa; 2006. p.129-39. 
Sousa GS, Pires MM, Rosado PL. Efeitos de políticas sobre a competitividade e eficiência da cadeia produtiva de biodiesel de dendê na região do Baixo Sul da Bahia. Revista Economica do Nordeste. 2011;42(4):827-42.

Superintendência de Estudos Econômicos e Sociais da Bahia - SEI. Sistema de Informações
Municipais. 2017. [acessado: 29 nov. 2017]. Disponível em: http://sim.sei.ba.gov.br/sim/ tabelas.wsp.

Virgens Filho AC. Programa de desenvolvimento do agronegócio da borracha no Estado da Bahia PRODEAB. Ilhéus: CEPLAC; 2003. 119p. 